\title{
Blockchain Technology for Winning Consumer Loyalty: Social Norm Analysis Using Structural Equation Modeling
}

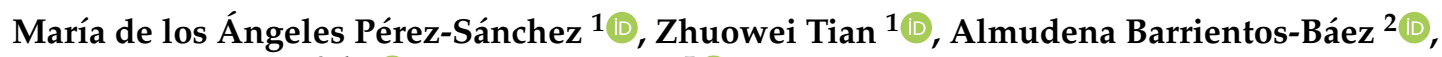 \\ José Gómez-Galán ${ }^{3,4, *(D)}$ and Hanliang $\mathrm{Li}^{5}$ (D) \\ 1 Department of Tourism and Hotel Management, School of Management, Zhejiang University, \\ N. 866 Yuhangtang Rd, Xihu, Hangzhou 310000, China; mariajaen@usal.es (M.d.l.Á.P.-S.); \\ tianzhuowei@zju.edu.cn (Z.T.) \\ 2 Faculty of Education, International University of La Rioja (UNIR), Avda. de la Paz, 26006 Logroño, Spain; \\ almudena.barrientosbaez@unir.net \\ 3 Department of Education, University of Extremadura, Avda. de Elvas, s/n, 06006 Badajoz, Spain; \\ jgomez@unex.es \\ 4 Cupey Campus, Ana G. Méndez University, Ave. Ana G. Méndez No.1399, San Juan 00926, Puerto Rico \\ 5 Department of Tourism Management, Zhejiang University City College, 51 Huzhou St, Gongshu District, \\ Hangzhou 310015, China; lihanl@zucc.edu.cn \\ * Correspondence: jogomez@uagm.edu; Tel.: +1-787-766-1717
}

Citation: Pérez-Sánchez, M.d.l.Á.;

Tian, Z.; Barrientos-Báez, A.;

Gómez-Galán, J.; Li, H. Blockchain Technology for Winning Consumer Loyalty: Social Norm Analysis Using Structural Equation Modeling.

Mathematics 2021, 9, 532. https://doi. org $/ 10.3390 /$ math9050532

Academic Editor: David Barilla

Received: 25 January 2021

Accepted: 26 February 2021

Published: 4 March 2021

Publisher's Note: MDPI stays neutral with regard to jurisdictional claims in published maps and institutional affiliations.

Copyright: (c) 2021 by the authors. Licensee MDPI, Basel, Switzerland. This article is an open access article distributed under the terms and conditions of the Creative Commons Attribution (CC BY) license (https:// creativecommons.org/licenses/by/ $4.0 /)$.

\begin{abstract}
Remarkable changes have taken in social operation mode and consumers' behavior mode because of the foot ban during the pandemic spread of COVID-19. Digital technologies such as Blockchain have shown potential in gaining competitive advantages for enterprises in such situations. This study aims to provide an insight into how to gain consumer loyalty through the use of modern and efficient Blockchain technology. In contrast to the current literature, this study combined the technology acceptance model of planned behavior theory, social exchange theory to explain the loyalty of an online travel agency (OTA) consumer. A self-administered questionnaire was used to collect data from citizens in Hangzhou, a city full of technological innovation atmosphere. Using structural equation modeling with SmartPLS@ , responses from 1403 citizens were analyzed. Social norm was discovered to have a positive and significant association with the consumers' attitude toward technology and thus enhancing the perceived usability and hedonism of OTA application, which can increase consumer loyalty. The findings suggested OTAs may gain consumers' loyalty through adopting Blockchain technology, and local governments have played a key role in creating such an environment. New technologies have become essential professional and social tools for society. The technological environment and Blockchain within the tourism sector are fundamental elements of China's economic engine.
\end{abstract}

Keywords: Blockchain; models; structural equation modeling; social norm; communication; COVID19; Chinese tourism; loyalty

\section{Introduction}

Throughout these years, the tourism industry has become one of the most important economic sectors worldwide for two reasons: Because of its share in the gross domestic product (GDP), and because of the capacity to generate employment that it can develop all over the world, thanks also to the important connection and indirect relationship it has with other sectors [1,2]. This situation is empirically demonstrable with China, where tourism specialization in recent years has played a fundamental role in promoting sustainable development [3-5].

In addition, China has become the largest source of international tourism, sending and receiving international tourists to and from many countries [6-8], several researchers think highly of the impact of Chinese tourism and Chinese tourists on the global economy $[9,10]$. 
However, COVID-19 has created a situation where many tourist companies have been closed and the travelers were grounded for security concerns, stopping the tourism industry and community life for months [11]. Because of the pandemic, global tourists also canceled their plan about visiting China, which affected the economy of this country to a large extent [12]. Another issue to remember is that, since the World Health Organization (WHO) declared the global pandemic of COVID-19, there has been a changing acceleration in the mode of social functioning and the mode of behavior of residents, especially in consumption [13].

Based on the foregoing and being aware that it is more costly to get a new client than to focus on the existing client, tourism companies in China are interested in online consumer loyalty, since electronic commerce is a reality in China and tourism is the protagonist of this new reality as it is a sector where electronic commerce has developed more rapidly [14].

With the popularity of mobile phones, iPads, and other wearable devices, mobile payment provides further convenience for e-commerce in tourism [15-17] This is especially true in an internet hot spot country like China, where the population of mobile payment users has exceeded 800 million in 2019 [18-20]. Online travel agencies (OTA) have become an important channel to sell hotel services thanks to an enormous amount of information, price comparison, and publication of comments that attract business travelers [21] and tourists.

Currently, there is a continuous increase in competition in the hotel distribution market, which is marked by the continuous growth and incorporation of services (search engine, opinions) of OTAs and incorporating providers in meta-search engines, turning these into a new channel for hotels and the new collaborative economy platforms.

Thanks to the rapid evolution of information and communication technologies (ICT) in recent years, a new marketing approach has emerged in the tourism sector. OTAs are essential protagonists of this technological change. The action of OTAs is the global market, and a single "click" separates them from their competitors. These companies have advantages over physical travel agencies which are conditioned by their geographical location, and their major competition is other nearby agencies.

OTAs are tourism companies, but they are also technology companies, and the management of this technology can be as or more important than the management of the tourism product itself. Thus, this new business model has unique characteristics, both because of its internal functioning, and because of the process related to the acquisition of tourism products and services, or even due to the marketing and communication strategies that it develops to build loyalty and get a greater number of customers.

About smart tourist destinations (STD), travel agencies (both online and offline) constitute an important element where, besides their intermediary and marketing role of the tourist offer, they act as inspiring and persuasive of the tourist before organizing the trip.

Blockchain is regarded as a paradigm shift in business practices, particularly in the OTAs context, thanks to its innovation in transactions, it is revolutionizing industries and is helping the economic impulse and its economic change on a global scale [22,23]. Several technologies such as smart contracts [24] and decentralized autonomous organizations [25] have been developed and used to make Blockchain technology more powerful. From a professional point of view, we can highlight the applications of this new technology in various fields, such as income management in inventory control, guest history, accommodation sector, and financial management. According to Waleed Rashideh, Blockchain technology is considered an appropriate technology to remove mediators from the supply chain of the tourism industry [26].

In addition to improving management efficiency, it is shown that the critical functions of Blockchain mechanisms have a positive impact on the loyalty program, as the asymmetric encryption platform has allowed companies to establish parameters that favor the customer wanting to repeat the same experience in the same destination. Thanks to this mechanism, guests can freely exchange or redeem their tokens. In this way, the greater value of the 
loyalty token will become a perception of a higher quality of service [27] favoring the loyalty process. Empirical evidence also has been found that the use of Blockchain will lead to the increase of Chinese consumer loyalty and value co-creation by enhancing their social interaction and satisfying intrinsic motivations [28].

However, as this technology is still at its early stage, security and cryptography researchers are required for further development [29]. Besides, there is still limited empirical research about Blockchain technology, the relationship between Blockchain technology and consumer loyalty remains unclear.

To address the approach shown above, the scope and objective of this article is to explore the effect that the social norm has on consumer loyalty with OTAs. Using Blockchain technology, a novel casual model is developed on the consumers' loyalty that is statistically significant and practical to predict consumer loyalty. Additionally, a more pragmatic picture and more comprehensive understanding of Blockchain technology were gained through this paper, discoveries that address the limitations and exclusion in existing theory and empirical studies of technology adoption were proposed.

\section{Background}

\subsection{The Implications of Blockchain Technology in the Tourism Industry}

The first application of Blockchain technology was in 2008 when Nakamoto proposed an electronic money trading system, based on distributed networks and cryptography, which was completely decentralized [30]. In this way, he defined Blockchain technology as "a decentralized technology for data and transaction management. The rest of the attributes provide security, anonymity, and data integrity with no external organization controlling the transactions. According to Yli-Huumo et al. [31], Blockchain is defined as a globally distributed ledger, which facilitates the movement of assets around the world in seconds, with minimal speed. The basic components of Blockchain are commercial networks, participants, assets, transactions, contracts, and account ledger [32].

Blockchain is revolutionizing the tourism industry by increasing the level of disintermediation, which had become a major problem since the early 2000s when OTA became popular with consumers. This new technology is especially suitable for products used by clients. Customers consider it carefully before buying, as in the tourism industry since trips are high participation products, which include important and expensive novelties and great personal relevance, therefore in these cases, Blockchain technology adds a valuable source of information that can reduce solidify favorable attitudes, drive purchasing decisions and supposed risks.

Blockchain has provided a new transaction tool to improve the efficiency, extensibility, security, implementation, and governance of electronic commerce [33]. Throughout this time, it has been considered an appropriate technology to eliminate intermediaries from the tourism market, since such technology has showed the potential to eliminate intermediaries from the supply chain of the tourism industry and prohibit the access of new intermediaries to this industry $[26,34]$. Önder and Treiblmaier proposed three proposals on Blockchain in the tourism industry for future research. Proposition 1: New forms of assessment and review technologies will lead to reliable rating systems; Proposition 2: The widespread adoption of cryptocurrencies will lead to new types of $\mathrm{C} 2 \mathrm{C}$ markets, and Proposition 3: Blockchain will lead to further disintermediation in the tourism industry [35].

There is evidence that Blockchain can benefit the tourism business as it provides a system that making data safe and transparent, at the same time that it can also help to establish a link between all the players in this industry with greater confidence, without the need of intermediaries [34].

In the tourism industry, customers are increasingly experienced tourists and for this reason and to satisfy their needs, new and innovative platforms have been built [36]. Blockchain technology can exert an important change in the travel habits of tourists because they meet the requirements demanded in the tourism industry since they provide trust, transparency, security, and credibility by adding transactions in a ledger that cannot be 
manipulated. This will lead to a disruption of the traditional way of operating in the tourism and hospitality industry soon.

The tourism industry has taken the lead in the adoption of Blockchain and cryptocurrencies. One example in China is the Tripio Company that has been developed within a Blockchain framework, with a technological system characterized by reliable transactions, a sustainable incentive mechanism, and a lower order price. Thanks to the use of Blockchain technology, it is possible to save time by locating passenger data in a token which facilitates the management of vouchers, streamlines operations, and saves transaction costs [37]. Airlines such as Air New Zealand, Air France-KLM, and Lufthansa have also adopted Blockchain and cryptocurrencies.

We dare to mention that with hospitality companies, some ways in which Blockchain technology is successful are guest tracking, food tracking, hotel outlets, business valuations, transaction mechanism secure and traceable, and incentive systems. In this way, professionals in the hospitality industry will collectively benefit.

Nowadays, Blockchain technology is materializing its primary purpose: to guarantee the stability and security of consumers. This aspect is relevant in public health, since the COVID-19 outbreak. Health and safety have become the top priority in the tourism industry. Hotels like Home Inn carry out epidemic prevention efforts based on this technology, providing a dynamic certification in the epidemic prevention work inspection, which makes them more verifiable, traceable and reliable. During the pandemic, significant progress was showed in the practical application of Blockchain technology in the hotel industry [34].

\subsection{Relationship with the Concept of Loyalty}

Customer loyalty is important concerning the company and for technological development. Despite the progress in this research field, changes produced by COVID-19 calling for deeper understanding. Loyalty is part of the tourist's decision process along with motivation and delight [38]. Multiple reasons drive tourists to visit a certain destination. Within the tourism sector and because of the great variety of destinations and accommodation and the existing competitiveness of markets, customer loyalty is necessary, understanding this as the repetition and recommendation of a certain destination or accommodation, a fact that is conditioned by satisfaction the clients. Currently, loyalty is considered an essential factor in marketing strategies [39].

According to Jacoby and Kyner [40], customer loyalty initially includes psychological aspects of evaluation and decision-making that shape attitudes and emotions about a brand, later turning into affective and repetitive buying behaviors. It is known that the most important thing for a tourist destination is to get the tourist to request the same products or services again and recommend the destination to others. An extremely loyal customer is considered being one who regularly uses the same service provided, prefers the provider company, adopts positive thoughts about it, and never considers using another provider for the service [41,42].

There is talk of false loyalty when a customer continues to maintain a relationship with the company or service for convenience or comfort even when his opinion of the company is not favorable. There is a relationship between customer loyalty and profitability, so for companies, keeping their customers is quite important, since it costs the company less to keep an existing customer than to attract new customers. There are three distinct indicators that can measure loyalty: the willingness to continue buying the same product, the willingness to buy more of the identical product, and the willingness to suggest the product to others $[43,44]$.

\subsection{The Effect of the Social Environment of the Consumer}

We can define attitude as the positive or negative feelings of a person and the evaluation of an aim behavior [45]. In this study, an attitude refers to the positive, supportive, negative, and negative evaluation of Tripio users, such as whether users like and will use 
Tripio as a regular hotel reservation way. In recent decades, researchers have put consistent effort into identifying the factors that lead to such an attitude, since users' attitude is believed to have a strong link with the level of consumers' loyalty $[46,47]$. The existing theoretical background supports that a more positive consumer attitude will lead to a positive value perception through emotional preferences $[48,49]$.

Esmaeilpour and Hoseini illustrate that consumers' attitudes are formed near the beginning of a purchase process, and affect their purchase decision based on their perception of utilitarian or hedonic [50]. It is shown that empirical studies further support this theoretical conception between consumer attitudes and perceived value [51]. Notably, Kim's work examined the relationship between consumers' brand attitude, hedonic value, and utilitarian value using data collected from 433 restaurant chain customers [52] or the study by Holbrook who also clarify this route through a database of customers and brand executives of 107 brands [53].

Conner and Armitage proved that a group of collectivists has a powerful effect in affecting a person's perception and judgment [54]. Social norms are defined as socially expected behavior patterns of individuals subject to person-to-person or person-to-group interactions. These norms dictate how they should behave in certain circumstances [55].

The social norm is an effective tool for explaining technology adoption behavior. For example, in their study by Earley and Ang, they maintained the positive effect of social norms on the adoption of wireless application protocol services by consumers [56]. Hung, $\mathrm{Ku}$, and Chang also confirmed the significant effect of a social norm on the acceptance of mobile commerce technology [57]. The social norm has been found to have the strongest effect on technological attitude because it can be treated as an acquisitive self-presentation to avoid displeasure from others or factors that repeat in consumption patterns [58-60]. This is especially obvious among the Chinese, as the attention on the shared aims of the group to which they belong, get along with group members, and appreciate what they have in common [61]. Smith and Louis argued that descriptive (i.e., what most people do themselves) and injunctive (what most people approve of) group norms will significantly influence people's attitude, behavioral intention, and behavior, which proves that social norm will affect decision making not only by what people say but also by what they do [62]

Considering the above, the following three hypotheses establish that:

Hypothesis 1 (H1). Individuals' perceptions of social norm positively influence their attitude toward application with Blockchain technology.

Hypothesis 2a (H2a). Consumers' attitude toward application with Blockchain technology positively influence the consumer's perceived usability of the application.

Hypothesis $\mathbf{2 b} \mathbf{( H 2 b ) . ~ C o n s u m e r s ' ~ a t t i t u d e s ~ t o w a r d ~ a p p l i c a t i o n ~ w i t h ~ B l o c k c h a i n ~ t e c h n o l o g y ~}$ positively influence the consumer's perceived hedonism of the application.

\subsection{The Influence of Consumers' Perception on the Loyalty to Blockchain Technology}

Loyalty was defined as the favorable attitude of an individual towards a retailer, which results in repeated purchase behavior. Multiple studies based on TAM have established a positive relationship between users' perceived usability with user intention, although no links with loyalty were found in that research $[63,64]$. Some studies have found that a sense of e-loyalty is exhibiting as the product is in line with the consumers' value, therefore, consumers' perceived usability has shown a positive influence on consumer loyalty $[65,66]$.

Seoyounget et al. showed that hedonic motivation can become a relevant predictor in the daily use and integration of technology [67]. Anil and Nikita also asserted this in their study of consumer intention to use technology [68]. The existing literature on the mobile tourism business argued that hedonic motivation can favorably influence both the integration of habitual technology use and the behavioral patterns of users [69].

Considering the above, the following two hypotheses establish that: 
Hypothesis 3 (H3). Consumers' perceived usability of the application positively influences the consumers' loyalty toward Blockchain technology.

Hypothesis 4 (H4). Consumers' perceived hedonism of the application positively influences the consumers' loyalty toward Blockchain technology.

All of the above is shown visually in Figure 1:

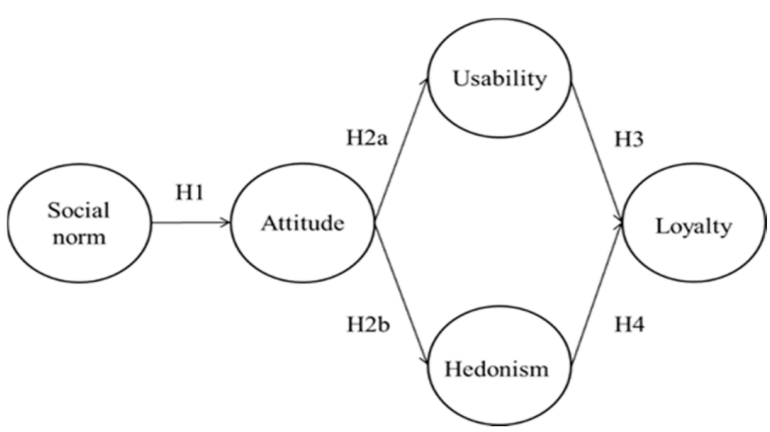

Figure 1. A suggestion for a path model explaining effects on loyalty in OTAs Proposed model. Source: Own elaboration.

\section{Materials and Methods}

\subsection{Model Basic Data}

In the south of Zhejiang Province, China, the city of Hangzhou has seen its economy and technological growth increase since it hosted the G20 in 2015, as well Tourism Industry has long been one of Hangzhou's competitive advantages in economic growth. As the birthplace of the largest e-commerce company Alibaba, Hangzhou has taken full advantage of new technologies, such as Smart Tourism Project [70] and City Brain [71]. Intelligent city emergency information entropy early warning system-take Hangzhou as an example [72].

Especially since the outbreak of COVID-19, health and safety become the top priority in the tourism industry, hotels "Chains like Home Inn" have carried out epidemic prevention work based on Blockchain technology, providing dynamic certification about the inspection of epidemic prevention work, which makes them more verifiable, traceable and reliable. This technological environment, along with social norms in China, is part of the interest of this study, as the habitats of Hangzhou are increasingly forced by their neighbors and relatives toward continued use of Blockchain technology.

Figure 2 shows the measure model basic data:

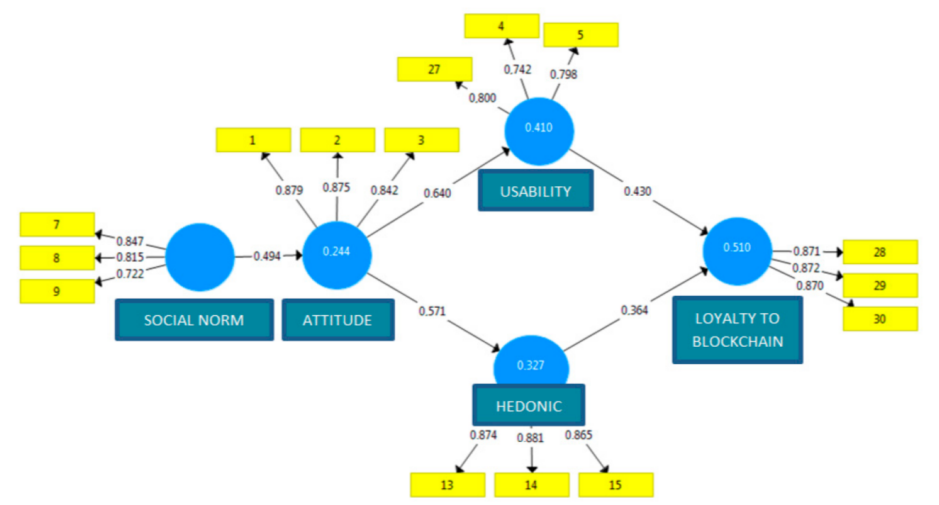

Figure 2. Measure model basic data. Source: Own Elaboration.

\subsection{Data Analysis}

This study was carried out through the method of modeling partial fewest squares structural equations (PLS-SEM). The reason we selected PLS was for its advantages in the 
study of human behavior [73] and its optimal predictive potential [74]. This approach does not require a normal data distribution $[75,76]$ and allows the use of reflective observed variables and a wide range of sample sizes [77].

In this study, the observed variables are reflective since the items share a common theme, they are interchangeable, and including an additional element in each construct would not change its conceptual nature [78]. The measurement invariance was analyzed using MICOM, an innovative approach developed for PLS-SEM [79-81] to carry out multigroup analysis through PLS-MGA.

\subsection{Data Collection and Sample}

The representative sample of this study was carried out in a randomized manner after completing a cluster study by age and sex across all populations as shown in (Table 1). To get a more precise assessment, the indicators of effect size (0.15) and power (0.90) were specified at a $95 \%$ confidence level $[73,82]$. The sample primarily included 128 more subjects, but arcading has been eliminated for one of the following reasons: (1) Did not respond to the online questionnaire; (2) Failures were found in the attention test questions; (3) He responded with the same score to all the items; and (4) Left some items unanswered.

Table 1. Details of the sample.

\begin{tabular}{ccccccc}
\hline Age & Men & \% & Women & \% & Total & \% \\
\hline$<25$ & 284 & $41.76 \%$ & 396 & $58.24 \%$ & 680 & $48.47 \%$ \\
$25-35$ & 193 & $44.16 \%$ & 244 & $55.84 \%$ & 437 & $31.15 \%$ \\
$36-45$ & 97 & $47.32 \%$ & 108 & $52.68 \%$ & 205 & $14.61 \%$ \\
$46-55$ & 37 & $61.67 \%$ & 23 & $38.33 \%$ & 60 & $4.27 \%$ \\
$>55$ & 13 & $61.90 \%$ & 8 & $38.10 \%$ & 21 & $1.50 \%$ \\
Total & 624 & $44.48 \%$ & 779 & $55.52 \%$ & 1403 & $100 \%$ \\
\hline
\end{tabular}

After removing the arcading, the total number of responses was 1403, with an overall response rate of $91.64 \%$. The overall sample size is greater than 200 subjects, the suitable size when structural equations are used [83].

In the study, women generated $55.52 \%$ of the data, as women pay more attention to pre-trip preparation [84]. It is worth mention that the majority (94.22\%) of the responders were under 45 , as OTA users are mainly young people.

\subsection{Variables and Measurements}

The independent variables of this study are the social norm, attitude toward Blockchain sites, usability, and hedonism. The residents' loyalty towards Blockchain sites is the dependent variable. A questionnaire was designed ad hoc to be applied online for data collection. To carry out the design of the scale, first, we proceeded to an analysis of the literature with the help and collaboration of an expert to identify the most appropriate variables, relationships, and measures for the proposed model, leading to the generation and validity of content $[85,86]$.

In the questionnaire's design, the principle of equanimity was considered to reduce the costs and methodological problems [87]. According to Huang and Dyer, the Delphi technique was used online to construct the definitive content of the relationships and elements [88,89]. Regarding item design, the work of Shaykh-Baygloo [90] were taken into account for place attachment. The items related to attitude have been designed considering the studies of Sinclair-Maragh and Hsu et al. [91,92]. The initial questionnaire included a pre-test and then went on to 18 items designed following the principles of brevity and simplicity using a Likert scale with 5 response alternatives (1: no agreement to 5: total agreement). Two control items related to gender and age were also included. As for the specific item design, the contributions of Sawang et al. were considered for the social norm [60]. We adjust the items to fit the Chinese consequence, since earn "face", or "Mian $\mathrm{Zi}$ " is important in Chinese culture [93], we develop the item "using Blockchain application 
will make me look good". The item attitude has been designed considering the studies of Kim and Bergel $[47,48]$. The design of the items related to perceived benefits was carried out based on the contributions of Gursoy et al. [94] and Su, Swanson, and Chen [95]. For the elaboration of the items on residents' intention to collaborate, the studies of Bakhsh et al. [96], Zheng, Yaoqi and Yali [97] and Lehto, O'Leary and Morrison [98] were used. Finally, for the elaboration of the items on consumers' loyalty, the studies of Kim and Bergel were consulted $[46,47]$ (Table 2).

Table 2. Descriptive and measurement model basic data.

\begin{tabular}{|c|c|c|c|c|c|c|}
\hline Items & $\begin{array}{c}\% \\
>0.50\end{array}$ & $\begin{array}{l}\text { Mean } \\
\geq 3\end{array}$ & $\begin{array}{l}\text { SD } \\
\leq 1.5\end{array}$ & $\begin{array}{l}\Lambda> \\
0.70\end{array}$ & $\begin{array}{l}\text { CR }> \\
0.70\end{array}$ & $\begin{array}{c}\text { AVE }> \\
0.50\end{array}$ \\
\hline SN1 My friends agree that I use the Blockchain in tourism & $52.72 \%$ & 2.64 & 1.09 & 0.847 & \multirow[b]{2}{*}{0.838} & \multirow[b]{2}{*}{0.635} \\
\hline $\begin{array}{l}\text { SN2 My family sees with good eyes that I use the } \\
\text { Blockchain in tourism }\end{array}$ & $59.39 \%$ & 2.97 & 1.16 & 0.815 & & \\
\hline SN3 My acquaintances approve that I use the Blockchain & $55.01 \%$ & 2.75 & 1.10 & 0.722 & \multirow{4}{*}{0.899} & \multirow{5}{*}{0.749} \\
\hline AT1 I am in favor of e-commerce through the Blockchain & $42.22 \%$ & 2.11 & 0.84 & 0.879 & & \\
\hline AT2 The use of Blockchain in tourism is positive & $44.16 \%$ & 2.21 & 0.91 & 0.975 & & \\
\hline AT3 I am fine with the use of Blockchain sites in tourism & $43.98 \%$ & 2.20 & 0.92 & 0.842 & & \\
\hline US1 Tourism Blockchain sites are easy to use & $44.89 \%$ & 2.24 & 0.98 & 0.800 & \multirow{4}{*}{0.824} & \\
\hline US2 Blockchain sites in tourism are accessible & $46.83 \%$ & 2.34 & 0.92 & 0.742 & & \multirow[t]{2}{*}{0.609} \\
\hline US3 Blockchain sites are fast & $49.86 \%$ & 2.49 & 0.95 & 0.798 & & \\
\hline HD1 Blockchain sites in tourism are entertaining & $51.12 \%$ & 2.56 & 1.02 & 0.874 & & \multirow{3}{*}{0.763} \\
\hline HD2 It's fun to use Blockchain sites in tourism & $51.52 \%$ & 2.58 & 1.06 & 0.881 & \multirow[t]{3}{*}{0.906} & \\
\hline HD3 It's pleasant to use Blockchain sites in tourism & $51.58 \%$ & 2.58 & 0.99 & 0.865 & & \\
\hline LY1 The next time I travel I will buy using Blockchain & $48.89 \%$ & 2.44 & 0.96 & 0.871 & & \multirow{3}{*}{0.758} \\
\hline LY2 I intend to buy a trip using Blockchain & $49.18 \%$ & 2.46 & 0.93 & 0.872 & \multirow[t]{2}{*}{0.904} & \\
\hline LY3 I will recommend the use of the Blockchain & $50.58 \%$ & 2.53 & 1.02 & 0.870 & & \\
\hline
\end{tabular}

Note: SN: Social norm; AT: Attitude towards Blockchain sites; US: Blockchain sites usability; HD: Blockchain hedonism; and LY: Loyalty to Blockchain (dependent variable).

Next, to identify the latent variables to which the items belong, an exploratory factor analysis with varimax rotation was carried out using the principal components method, Bartlett's sphericity test, and Cronbach's alpha reliability statistic, and the Kaiser-test. Meyer-Olkin (KMO). This process is shared in research by other scientists [99,100]. Subsequently, a series of analyzes got a structure of five latent variables (Table 2). Those variables are SN: Social norm; AT: Attitude towards Blockchain; US: Blockchain sites usability; HD: Blockchain sites hedonism; and LY: Loyalty to Blockchain sites (dependent variable). The scale initially included 18 items, of which three items corresponding to the latent variables $\mathrm{AT}, \mathrm{HD}$, and $\mathrm{LY}$ were eliminated as they were reflective items. The nature of these latent variables was not significantly altered. The results of the factorial analysis verified that the general reliability of the questionnaire increased when these items were eliminated (Cronbach's alpha changed from 0.83 to 0.85 ). Including three items in the latent variables was also accepted because the items have a reduced correlation with other items and a correlation between them greater than $0.70[101,102]$. The questionnaire was applied online through a WeChat form, which is the most used social network. Service in China and major social media platform for computer communication [103] in May 2020.

\section{Results}

\subsection{Descriptive Data}

As shown in (Table 2), all the items were allocated scores (100\%). Approximately 50\% of the maximum value would have been obtained by the items if all the subjects had given them the highest score (5). The most valued item is that related to SN2 ("My family sees with good eyes that I use the Blockchain in tourism") and the lowest valued item is AT1 ("I am in favor of e-commerce through the Blockchain"). Because the standard deviation of all items is less than the half of the mean, it can be declared that there are no extreme values or balances. 
Regarding item design, the contributions of Sawang, Yuan, and Salim were considered for the social norm [60]. We adjust the items to fit the Chinese consequence, as earn "face", or "Mian Zi" is important in Chinese culture [93], we develop the item "using Blockchain application will make me look good". The item attitude has been designed considering the studies of several authors $[47,48]$. The design of the items related to usability and hedonic was carried out based on the contributions of Khechine, Raymond, and Augier [104] and $\mathrm{He}$, Zhang, and Zeng [105]. Finally, for the elaboration of the items on consumers' loyalty, the studies of Bergel and Brock [46], and Kim and Lee [47] were consulted.

\subsection{PLS context of Structural Equations: Analysis of the Model}

Firstly, to test the five hypotheses of the proposed causal model, the measurement model was evaluated, since in this way the belonging of the observable variables to their latent variable is analyzed [106]. Table 5 shows that the individual reliability study presented that the detected variables reached the minimum level required or even a much higher value $(\lambda \geq 0.70)$. In the composite reliability study $(\mathrm{CR})$ it was shown that all values were above 0.70 (Table 5) and that the measurement model was internally consistent. Therefore, all the observed variables measured their corresponding latent variable $[106,107]$.

For the evaluation of the convergent validity of the model, the average extracted variance (AVE) was evaluated, since its calculation provides information on the amount of variance got by a construct of its indicators. In all cases, the result was greater than 0.50 [108] (Table 3). To analyze the discriminant validity, the square root of the average variance extracted (AVE) was examined and in this way, it was verified that it was greater than the shared variance between the latent variable and the other variables (Table 4) $[109,110]$. When the matrix of cross-loading factors was got, the results showed the items were more correlated with their variables than with others [106] (Table 3).

Table 3. Cross loads.

\begin{tabular}{cccccc}
\hline Items & SN & AT & US & HD & LY \\
\hline SN1 & $\mathbf{0 . 8 4 7}$ & 0.428 & 0.496 & 0.507 & 0.511 \\
SN2 & $\mathbf{0 . 8 1 5}$ & 0.371 & 0.436 & 0.489 & 0.460 \\
SN3 & $\mathbf{0 . 7 2 2}$ & 0.377 & 0.377 & 0.504 & 0.407 \\
AT1 & 0.436 & $\mathbf{0 . 8 7 9}$ & 0.555 & 0.492 & 0.510 \\
AT2 & 0.428 & $\mathbf{0 . 8 7 5}$ & 0.560 & 0.519 & 0.541 \\
AT3 & 0.418 & $\mathbf{0 . 8 4 2}$ & 0.547 & 0.471 & 0.500 \\
US1 & 0.501 & 0.532 & $\mathbf{0 . 8 0 0}$ & 0.571 & 0.658 \\
US2 & 0.365 & 0.434 & $\mathbf{0 . 7 4 2}$ & 0.393 & 0.395 \\
US3 & 0.402 & 0.522 & $\mathbf{0 . 7 9 8}$ & 0.446 & 0.431 \\
HD1 & 0.524 & 0.492 & 0.521 & $\mathbf{0 . 8 7 4}$ & 0.542 \\
HD2 & 0.547 & 0.458 & 0.491 & $\mathbf{0 . 8 8 1}$ & 0.512 \\
HD3 & 0.572 & 0.540 & 0.590 & $\mathbf{0 . 8 6 5}$ & 0.587 \\
LY1 & 0.505 & 0.500 & 0.570 & 0.556 & $\mathbf{0 . 8 7 1}$ \\
LY2 & 0.491 & 0.561 & 0.579 & 0.539 & $\mathbf{0 . 8 7 2}$ \\
LY3 & 0.517 & 0.501 & 0.558 & 0.548 & $\mathbf{0 . 8 7 0}$ \\
\hline
\end{tabular}

Note: SN: Social norm; AT: Attitude towards Blockchain sites; US: Blockchain sites usability; HD: Blockchain sites hedonism; and LY: Loyalty to Blockchain sites (dependent variable).

Table 4. HTML index.

\begin{tabular}{cccccc}
\hline & SN & AT & US & HD & LY \\
\hline SN & - & & & & \\
AT & 0.642 & - & & & \\
US & 0.771 & 0.838 & - & - & \\
HD & 0.811 & 0.678 & 0.784 & 0.743 & - \\
LY & 0.748 & 0.715 & 0.832 & - \\
\hline
\end{tabular}

Note: SN: Social norm; AT: Attitude towards Blockchain sites; US: Blockchain sites usability; HD: Blockchain sites hedonism; and LY: Loyalty to Blockchain sites (dependent variable). 
In particular, the finding was that there was no collinearity because the VIF value of each predictor variable was greater than 0.20 and less than 5 [111,112]. Finally, (heterotraitmonotrait correlation relationship) the value of the HTMT index in all cases was less than 1 [113] (Table 4).

Table 5. Discriminant validity [114].

\begin{tabular}{cccccc}
\hline & SN & AT & US & HD & LY \\
\hline SN & $\mathbf{0 . 7 9 7}$ & & & & \\
AT & 0.494 & $\mathbf{0 . 8 6 5}$ & & & \\
US & 0.551 & 0.640 & $\mathbf{0 . 7 8 1}$ & & \\
HD & 0.628 & 0.571 & 0.615 & $\mathbf{0 . 8 7 3}$ & \\
LY & 0.579 & 0.598 & 0.654 & 0.628 & $\mathbf{0 . 8 7 1}$ \\
\hline
\end{tabular}

Note: SN: Social norm; AT: Attitude towards Blockchain sites; US: Blockchain sites usability; HD: Blockchain sites hedonism; and LY: Loyalty to Blockchain sites (dependent variable).

For the discriminant validity, the square root of the average variance extracted (AVE) was verified and it was found to be greater than the shared variance between the latent variable and the rest of the variables [114,115]. Cross-loading factors were displayed in Table 4.

Concerning the evaluation of the structural model, which relates the latent variables with others [74], it was first confirmed that there was no multicollinearity between the latent variables since in all cases the inflation index of the variance was lower at 3.3 , the condition index was lower than 30 and the tolerance level was higher than 0.20 [116-118]. About the sign of the relationships, it was found that all had a similar positive sign as their corresponding hypothesis, so no hypothesis had to be rejected.

On other hand, and concerning the magnitude of the causal relationships, it was found that in all cases the trajectory coefficient $(\beta)$ (standardized regression weights) reached levels above the optimal level $(\beta \geq 0.3)$ [74]. Because of this, the causal relationships with the lowest weight were those associated with H4 $(\beta=0.364)$. However, the relationship with the highest weight was $\mathrm{H} 2 \mathrm{a}(\beta=0.640)$. To analyze the importance of the relationships, a bootstrapping analysis was carried out with 500 subsamples and 200 cases [119]. All direct relationships reached a high significance $(\mathrm{P} \leq 0.05)$. Therefore, all hypotheses are accepted (Table 4).

Tables 4 and 6 showing all the hypotheses were accepted, and the model presents satisfactory structural and sufficient predictive potential.

Table 6. Relationship data.

\begin{tabular}{cccccc}
\hline Hip & Relat. & $\begin{array}{c}\text { Paths } \\
(\boldsymbol{\beta})\end{array}$ & $\mathbf{t}$ & $p$ Val. & Conf. \\
\hline H1 & SN $\rightarrow$ AT & 0.494 & 21.244 & 0.000 & Yes \\
H2a & AT $\rightarrow$ US & 0.640 & 33.426 & 0.000 & Yes \\
H2b & AT $\rightarrow$ HD & 0.571 & 27.488 & 0.000 & Yes \\
H3 & US $\rightarrow$ LY & 0.430 & 18.273 & 0.000 & Yes \\
H4 & HD $\rightarrow$ LY & 0.364 & 15.403 & 0.000 & Yes \\
\hline
\end{tabular}

Note: SN: Social norm; AT: Attitude towards Blockchain sites; US: Blockchain sites usability; HD: Blockchain sites hedonism; and LY: Loyalty to Blockchain sites (dependent variable).

\subsection{The Analysis of the Predictive Validity of the Model}

The Q2 value and the goodness of fit (GoF) test [120] were analyzed to find the predictive validity of the proposed model and the $\mathrm{R} 2$ indicator was also calculated. The R2 indicator (coefficient of determination) is related to the amount of variance of a latent dependent variable that is explained by other constructs of the model [112]. In this study, the value of $\mathrm{R} 2$ relative to the dependent construct (LY) was greater than the minimum acceptable value of $0.500(\mathrm{R} 2=0.510)($ Table 6$)$. The $\mathrm{Q} 2$ indicator was calculated using a prediction 
based on redundancy $[112,121]$. This was developed by Henseler and Schlagel $[122,123]$. This study shows values above zero $(\mathrm{Q} 2 \geq 0)$ in all cases, showing that the model has significant predictive potential.

To corroborate the result, the GoF (Goodness-of-Fit) test was used, which ranges between 0 and 1 and represents the geometric mean between the mean of R2 and the mean of the AVE test (endogenous constructs only). This test reached a value of 0.518, which is higher than 0.360 (minimum acceptable value) [121]. Therefore, we can affirm that the model presents satisfactory structural properties and sufficient predictive potential.

\subsection{Multigroup Analysis}

First, a multigroup PLS-MGA analysis was performed to analyze the existence of significant causal differences between men and women (hypothesis 6). This method is very useful for comparing gender differences [124]. The analysis was carried out in the PLSSEM structural equation model using the MGA test [123] and the permutation test [125] conservatively [74]. First, and before performing the multigroup analysis, the invariance of the measurement was first verified using the three-step procedure called MICOM [80] (Table 7).

Table 7. MICOM.

\begin{tabular}{ccc}
\hline \multirow{2}{*}{ Latent Variable } & \multicolumn{2}{c}{ Man } \\
\cline { 2 - 3 } & $\mathbf{R}^{\mathbf{2}}>\mathbf{0 . 2 0}$ & $\mathbf{Q}^{\mathbf{2}}>\mathbf{0}$ \\
\hline AT & 0.244 & 0.181 \\
US & 0.410 & 0.246 \\
HD & 0.327 & 0.245 \\
LY & 0.510 & 0.384 \\
GoF $>0.360$ & & 0.518 \\
\hline
\end{tabular}

Note: SN: Social norm; AT: Attitude towards Blockchain sites; US: Blockchain sites usability; HD: Blockchain sites hedonism; and LY: Loyalty to Blockchain sites (dependent variable).

The first step that was taken was the examination of the invariance of the configuration, the second step was the verification of the invariance of the composition, and the third step was to verify the invariance of the means (step 3a) and the variances (step 3b). The first step involves verifying that identical indicators, data processing, and algorithm settings have been used in both groups of samples [112]. Regarding the invariance of the composition (step 2), it has when the composite scores are generated equally across groups [126]. The results show both groups can be compared using PLS-MGA because invariance has been confirmed in step 1 and step 2, but not in both parts of the step.

Table 8 shows us the differences in trajectory between men and women, and the meaning of these differences, both in the permutation test and in the MGA analysis. With the AMS analysis, a p-value less than 0.05 or greater than 0.95 , shows that there is a level of significance that must be considered between trajectory coefficients associated with a specific hypothesis. So this causal relationship is significantly different between both groups $[79,126]$. Regarding the permutation test, the differences are significant only when the p-value is less than 0.05 . Based on the results of both indicators, we can verify that there are significant differences between men and women in the third causal relationship of the model $(\mathrm{H} 2 \mathrm{~b})$. Therefore, it can be verified that the results of men and women are very similar and the sixth hypothesis (H7) is confirmed. 
Table 8. Results of Invariance Measurement Testing Using Permutation.

\begin{tabular}{|c|c|c|c|c|c|c|c|c|c|c|c|}
\hline \multirow{3}{*}{ LV } & \multirow{3}{*}{$\begin{array}{c}\text { Step } 1 \\
\text { Configural } \\
\text { Invariance }\end{array}$} & \multicolumn{3}{|c|}{ Step 2} & \multicolumn{3}{|c|}{ Step 3 (I) } & \multicolumn{3}{|c|}{ Step 3 (II) } & \multirow{3}{*}{$\begin{array}{c}\text { Full } \\
\text { Measurement } \\
\text { Invariance } \\
\text { Established }\end{array}$} \\
\hline & & \multicolumn{2}{|c|}{$\begin{array}{l}\text { Compositional } \\
\text { Invariance }\end{array}$} & \multirow{2}{*}{$\begin{array}{c}\text { Partial } \\
\text { Measurement } \\
\text { Invariance } \\
\text { Established }\end{array}$} & \multicolumn{3}{|c|}{ Equal Mean Assessment } & \multicolumn{3}{|c|}{ Equal Variance Assessment } & \\
\hline & & $C=1$ & $\begin{array}{l}\text { Confid. } \\
\text { Interval }\end{array}$ & & Dif & $\begin{array}{l}\text { Confid. } \\
\text { Interval }\end{array}$ & Equal & Dif & $\begin{array}{l}\text { Confi. } \\
\text { Interval }\end{array}$ & Equal & \\
\hline $\mathrm{SN}$ & Yes & 0.999 & $\begin{array}{l}{[0.997,} \\
0.999]\end{array}$ & Yes & -0.059 & $\begin{array}{c}{[-0.107,} \\
0.107]\end{array}$ & Yes & 0.232 & $\begin{array}{c}{[-0.137,} \\
0.128]\end{array}$ & No & No \\
\hline AT & Yes & 1.000 & $\begin{array}{l}{[1.000,} \\
1.000]\end{array}$ & Yes & 0.075 & {$\left[\begin{array}{c}-0.106, \\
0.107]\end{array}\right.$} & Yes & 0.353 & {$\left[\begin{array}{c}-0.177, \\
0.177]\end{array}\right.$} & No & No \\
\hline US & Yes & 0.999 & $\begin{array}{l}{[0.998,} \\
0.999]\end{array}$ & Yes & 0.015 & {$\left[\begin{array}{c}{[-0.100} \\
0.101]\end{array}\right.$} & Yes & 0.348 & $\begin{array}{c}{[-0.152,} \\
0.147]\end{array}$ & No & No \\
\hline HD & Yes & 1.000 & $\begin{array}{l}{[1.000,} \\
1.000]\end{array}$ & Yes & -0.029 & $\begin{array}{c}{[-0.096,} \\
0.104]\end{array}$ & Yes & 0.110 & $\begin{array}{c}{[-0.135,} \\
0.131]\end{array}$ & Yes & Yes \\
\hline LY & Yes & 1.000 & $\begin{array}{l}{[1.000,} \\
1.000]\end{array}$ & Yes & -0.031 & $\begin{array}{c}{[-0.105} \\
0.098]\end{array}$ & Yes & 0.161 & $\begin{array}{c}{[-0.154,} \\
0.146]\end{array}$ & Yes & Yes \\
\hline
\end{tabular}

Note: SN: Social norm; AT: Attitude towards Blockchain sites; US: Blockchain sites usability; HD: Blockchain sites hedonism; and LY: Loyalty to Blockchain sites (dependent variable).

Tables 8 and 9 showing the result of multigroup between different gender, it can be verified that the results of men and women are very similar to each other.

Table 9. Multigroup Analysis.

\begin{tabular}{cccccccc}
\hline \multirow{2}{*}{ Hyp. } & \multirow{2}{*}{ Relationship } & & & & & \multicolumn{2}{c}{$p$-Value Difference } \\
& & Men & Women & PathPathdif. & Henseler's MGA & Permutation Test & Supported \\
\hline H1 & SN $\rightarrow$ AT & 0.536 & 0.455 & 0.081 & 0.078 & 0.066 & No/No \\
H2a & AT $\rightarrow$ US & 0.676 & 0.601 & 0.075 & 0.061 & 0.066 & No/No \\
H2b & AT $\rightarrow$ HD & 0.632 & 0.515 & 0.118 & 0.007 & 0.002 & Yes/Yes \\
H3 & US $\rightarrow$ LY & 0.431 & 0.425 & 0.006 & 0.912 & 0.904 & No/No \\
H4 & HD $\rightarrow$ LY & 0.388 & 0.346 & 0.042 & 0.404 & 0.386 & No/No \\
\hline
\end{tabular}

Note: SN: Social norm; AT: Attitude towards Blockchain sites; US: Blockchain sites usability; HD: Blockchain sites hedonism; and LY: Loyalty to Blockchain sites (dependent variable).

Table 10 shows the result of the multigroup divided into different age groups. It can be seen that the results of the study show that the youngest age group exponentially exceeds the rest of the ages. This is so because young people are more familiar with the use of digital tools, ICT, and online platformization. This includes the use of Blockchain.

Table 10. Multigroup Ages Analysis.

\begin{tabular}{ccccc}
\hline Hyp. & Relationship & $<\mathbf{2 5}$ & $\mathbf{2 5 - 4 5}$ & $>\mathbf{4 5}$ \\
\hline H1 & SN $\rightarrow$ AT & 0.685 & 0.482 & 0.161 \\
H2a & AT $\rightarrow$ US & 0.626 & 0.422 & 0.125 \\
H2b & AT $\rightarrow$ HD & 0.632 & 0.392 & 0.224 \\
H3 & US $\rightarrow$ LY & 0.658 & 0.449 & 0.126 \\
H4 & HD $\rightarrow$ LY & 0.526 & 0.498 & 0.210 \\
\hline
\end{tabular}

Note: SN: Social norm; AT: Attitude towards Blockchain sites; US: Blockchain sites usability; HD: Blockchain sites hedonism; and LY: Loyalty to Blockchain sites (dependent variable).

\section{Conclusions}

\subsection{Evidence Obtained}

Our results represent a contribution to the study of Blockchain technology in tourism and consumers' loyalty to OTAs. This will be especially important after the pandemic since OTAs are urgently needed to gain market share during revitalizing the tourism industry.

First, the responses to the items show that social norms have a significant impact on consumers' technology adoption by changing their attitude toward it. Blockchain technology was perceived as a new technology that is worth learning. The local government 
played an important role in building such a social norm, which is an excellent demonstration of how the local government can discharge the responsibility of revitalizing the tourism market after the health crisis.

Secondly, in this study, a significant model of the consumers' loyalty toward OTAs has been generated through technology adoption. It is effective and practical for OTAs to generate loyalty by adopting new technology such as Blockchain. The model allows integrating technology and OTAs through market orientation, which suggests OTAs can increase market share through technological innovation.

Thirdly, it is noteworthy that the positive attitude of consumers toward Blockchain technology influences their perceived usability and hedonism of the application adopted such technology. Therefore, these attitudes are causally and significantly linked to the level of consumers' loyalty towards OTAs.

The variables and their relationships included in the proposed model identify the attitude toward Blockchain technology, highlighting the importance of cooperation. After all, the recovery of the tourism industry requires the joint effort of all agents and institutions. The major limitation of this research has been related at all times to the selection and combination of the internal and external variables included in the proposed model, because of the great diversity of variables in the literature when studying consumer loyalty. The second limitation would be related to the use of a sample from a specific city like Hangzhou, although it can also impact consumer attitudes in a broader area.

Also, and we believe that they would be of great relevance, the next line of research could be to extend behavioral loyalty analysis to constant use of the said app as well as actual purchases, in which case a dashboard data-driven research methodology and implement it consequently, to visualize long-term consumer behavior.

In short, smart destinations help by directly and indirectly collecting and processing data from potential customers and users in general of tourism services, with the sole objective of providing a better service to residents and tourists. Those places that have committed to working to become smart destinations can gain recognition from the markets, especially if they focus their data and knowledge on aspects that are now key such as security. They show that they work in a serious and committed way with society to help it and improve resident's quality of life, visitors, and tourists. Digitization and, a clear example of it, Blockchain technology, is a pillar to obtain economic benefits and improve positioning in a given market niche, while providing quality in the customer experience, facilitating the purchase of a tourist service/product, and later loyalty.

\subsection{Implications for Practice and Policy}

Firstly, the study reveals that social norms will lead consumers to grow positive attitudes toward new technology, and thus motivates them to seek novelty applications. Such a unique atmosphere might be gained by building a smart destination, for citizens were educated through everyday life interact with smart applications. The development of smart destinations should not leave residents behind, by encouraging them to learn new technology, the tourism industry may take advantage of such social norms indirectly.

Secondly, the study showed that consumers will perceive higher utilitarian value and hedonic value when using the application with Blockchain. This implies that OTA should adopt this new technology to gain a helpful position in marketing.

Author Contributions: Conceptualization, methodology, software, validation, formal analysis, investigation, resources, data curation, writing - original draft preparation and project administration, M.d.l.Á.P.-S.; Z.T.; A.B.-B.; J.G.-G. and H.L.; writing-review and editing, visualization and supervision, M.d.l.Á.P.-S.; Z.T.; A.B.-B. and J.G.-G. All authors have read and agreed to the published version of the manuscript.

Funding: This research received no external funding This research did not receive any specific grant from funding agencies in the public, commercial, or not-for-profit sectors. 
Institutional Review Board Statement: The study was conducted according to the guidelines of the Declaration of Helsinki.

Informed Consent Statement: Informed consent was obtained from all subjects involved in the study.

Data Availability Statement: Data available on request due to privacy and ethical restrictions. Main data is contained within the article.

Acknowledgments: We are very grateful to the people who participated in this study and made the fieldwork feasible. Without their help, the research would have been impossible.

Conflicts of Interest: The authors declare no conflict of interest.

\section{References}

1. Assaf, A.G.; Li, G.; Song, H.; Tsionas, M.G. Modeling and forecasting regional tourism demand using the bayesian global vector autoregressive (BGVAR) model. J. Travel Res. 2018, 58, 383-397. [CrossRef]

2. Dogru, T.; Suess, C.; Sirakaya-Turk, E. Why do some countries prosper more in tourism than others? Global competitiveness of tourism development. J. Hosp. Tour. Res. 2020, 45, 215-256. [CrossRef]

3. Giorgi, E.; Cattaneo, T.; Ni, M.; Alatriste, R.E. Sustainability and effectiveness of Chinese outline for national tourism and leisure. Sustainability 2020, 12, 1161. [CrossRef]

4. Canmian, L.; Ruyun, Z.; Min, W.; Jing, X. Measurement and prediction of regional tourism sustainability: An analysis of the Yangtze river economic zone, China. Sustainability 2018, 10, 1321.

5. Zuo, B.; Huang, S. Revisiting the tourism-led economic growth hypothesis: The case of China. J. Travel Res. Int. Assoc. Travel Res. Mark. Prof. 2018, 57, 151-163.

6. He, X.; Su, L.; Swanson, S.R. The service quality to subjective well-being of Chinese tourists connection: A model with replications. Curr. Issues Tour. 2020, 23, 1-17. [CrossRef]

7. Liu, Y.; Huang, K.; Bao, J.; Chen, K. Listen to the voices from home: An analysis of Chinese tourists' sentiments regarding Australian destinations. Tour. Manag. 2018, 71, 337-347. [CrossRef]

8. Ying, T.; Wen, J. Exploring the male Chinese tourists' motivation for commercial sex when travelling overseas: Scale construction and validation. Tour. Manag. 2018, 70, 479-490. [CrossRef]

9. Hoa, T.V.; Turner, L.; Vu, J. Economic impact of Chinese tourism on Australia: A new approach. Tour. Econ. 2018, $24,677-689$.

10. Shehzad, K.; Liu, X.; Rauf, A.; Arif, M.; Amin, W. Revolutionising tourism development in China: An effective role of ICT and Western silk road project. Asia Pac. J. Tour. Res. 2019, 24, 965-977. [CrossRef]

11. Zheng, Y.; Goh, E.; Wen, J. The effects of misleading media reports about COVID-19 on Chinese tourists' mental health: A perspective article. Anatolia 2020, 31, 337-340. [CrossRef]

12. Hoque, A.; Shikha, F.; Hasanat, M.; Arif, I.; Abdul Hamid, A.B. The effect of coronavirus (COVID-19) in the tourism industry in China. Asian J. Multidiscip. Stud. 2020, 3, 52-58.

13. Harrisson-Boudreau, J.-P.; Dahl, B. COVID-19 \& Ecommerce in Canada-A Performance Index from 50 Online Stores. Available online: https: / / www.absolunet.com/hubfs/6890475/PDF-Premium-Downloads/eCommerce-COVID-19-Crisis-CanadaAbsolunet-Index.pdf (accessed on 19 December 2020).

14. Fuyi, L.; Stacey, F.; Gary, G. E-commerce and industrial upgrading in the Chinese apparel value chain. J. Contemp. Asia 2018, 49, 24-53.

15. Madan, K.; Yadav, R.; Phau, I. Understanding and predicting antecedents of mobile shopping adoption: A developing country perspective. Asia Pac. J. Mark. Logist. 2018, 30, 139-162. [CrossRef]

16. Morosan, C.; Defranco, A. Co-creating value in hotels using mobile devices: A conceptual model with empirical validation. Int. J. Hosp. Manag. 2016, 52, 131-142. [CrossRef]

17. Rita, P.; Oliveira, T.; Estorninho, A.; Moro, S.; Volo, S.; Scott, N. Mobile services adoption in a hospitality consumer context. Int. J. Cult. Tour. Hosp. Res. 2018, 1, 143-158. [CrossRef]

18. Chandra, S.; Srivastava, S.C.; Theng, Y.L. Evaluating the role of trust in consumer adoption of mobile payment systems: An empirical analysis. Commun. Assoc. Inf. Syst. 2010, 27, 561. [CrossRef]

19. Qasim, H.; Abu-Shanab, E. Drivers of mobile payment acceptance: The impact of network externalities. Inf. Syst. Front. 2016, 18, 1021-1034. [CrossRef]

20. Liébana-Cabanillas, F.; Marinkovic, V.; de Luna, I.R.; Kalinic, Z. Predicting the determinants of mobile payment acceptance: A hybrid sem-neural network approach. Technol. Forecast. Soc. Chang. 2018, 129, 117-130. [CrossRef]

21. Chang, Y.W.; Hsu, P.Y.; Lan, Y.C. Cooperation and competition between online travel agencies and hotels. Tour. Manag. 2019, 71, 187-196. [CrossRef]

22. Delmolino, K.; Arnett, M.; Kosba, A.; Miller, A.; Shi, E. Step by step towards creating a safe smart contract: Lessons and insights from a cryptocurrency lab. In International Conference on Financial Cryptography and Data Security; Springer: Berlin/Heidelberg, Germany, 2016; pp. 79-94. 
23. Kosba, A.; Miller, A.; Shi, E.; Wen, Z.; Papamanthou, C. Hawk: The blockchain model of cryptography and privacy-preserving smart contracts. In Proceedings of the 2016 IEEE Symposium on Security and Privacy (SP), San Jose, CA, USA, 22-26 May 2016; IEEE: New York, NY, USA, 2016; pp. 839-858.

24. Shermin, V. Disrupting governance with blockchains and smart contracts. Strateg. Chang. 2017, 26, 499-509. [CrossRef]

25. Savron, L. How blockchain technology could change our lives. Ursidae Undergrad. Res. J. Univ. North. Colo. $2019,8,10$.

26. Rashideh, W. Blockchain technology framework: Current and future perspectives for the tourism industry. Tour. Manag. 2020, 80, 104125. [CrossRef]

27. Kizildag, M.; Dogru, T.; Zhang, T.; Altin, M.; Ozturk, A.B. Blockchain: A paradigm shift in business practices. Int. J. Contemp. Hosp. Manag. 2018, 32, 953-975. [CrossRef]

28. Wang, L.; Luo, X.R.; Lee, F. Unveiling the interplay between blockchain and loyalty program participation: A qualitative approach based on BubiChain. Int. J. Inf. Manag. 2019, 49, 397-410. [CrossRef]

29. Kumar, N.; Aujla, G.S.; Garg, S.; Kaur, K.; Rajan, R.; Garg, S. Renewable energy-based multi-indexed job classification and container management scheme for sustainability of cloud data centers. IEEE Trans. Ind. Inform. 2018, 15, 2947-2957. [CrossRef]

30. Nakamoto, S. Bitcoin: A Peer-To-Peer Electronic Cash System. Available online: https://metzdowd.com (accessed on 10 September 2020).

31. Yli-Huumo, J.; Ko, D.; Choi, S.; Park, S.; Smolander, K. Where is current research on blockchain technology?-A systematic review. PLoS ONE 2016, 11, e0163477. [CrossRef]

32. Ying, W.; Jia, S.; Du, W. Digital enablement of blockchain: Evidence from HNA group. Int. J. Inf. Manag. 2018, 39, 1-4. [CrossRef]

33. Liu, Z.; Li, Z. A blockchain-based framework of cross-border e-commerce supply chain. Int. J. Inf. Manag. 2019, 52, 102059. [CrossRef]

34. Willie, P. Can all sectors of the hospitality and tourism industry be influenced by the innovation of blockchain technology? Worldw. Hosp. Tour. Themes 2019, 11, 112-120. [CrossRef]

35. Önder, I.; Treiblmaier, H. Blockchain and tourism: Three research propositions. Ann. Tour. Res. 2018, 72, 180-182. [CrossRef]

36. Colombo, E.; Baggio, R. Tourism distribution channels: Academic, industry and government bridges. Bridg. Tour. Theory Pract. 2017, 8, 289-301.

37. Karinsalo, A.; Halunen, K. Smart contracts for a mobility-as-a-service ecosystem. In Proceedings of the 2018 IEEE International Conference on Software Quality, Reliability and Security Companion (QRS-C), Lisbon, Portugal, 16-20 July 2018; IEEE: Lisbon, Portugal, 2018; pp. 135-138.

38. Hu, B.; Huang, W.; Yan, S.; Liu, G.; Zhang, T. Business model design and customer loyalty: The mediating role of customer citizenship behavior. Sustainability 2020, 12, 7047. [CrossRef]

39. Lee, H.N.; Lee, A.S.; Liang, Y.W. An empirical analysis of brand as symbol, perceived transaction value, perceived acquisition value and customer loyalty using structural equation modeling. Sustainability 2019, 11, 2116. [CrossRef]

40. Jacoby, J.; Kyner, D.B. Brand loyalty vs. repeat purchasing behavior. J. Mark. Res. 1973, 10, 1-9. [CrossRef]

41. Pamies, S.D. De la Calidad de Servicio a la Fidelidad del Cliente; ESIC Editorial: Madrid, Spain, 2004.

42. Latif, F.; Pérez, A.; Sahibzada, U.F. Corporate social responsibility (CSR) and customer loyalty in the hotel industry: A crosscountry study. Int. J. Hosp. Manag. 2020, 89, 102565. [CrossRef]

43. Bahri-Ammari, N.; Bilgihan, A. Customer retention to mobile telecommunication service providers: The roles of perceived justice and customer loyalty program. Int. J. Mob. Commun. 2019, 17, 82. [CrossRef]

44. Wang, C.J. From emotional labor to customer loyalty in hospitality: A three-level investigation with the JD-R model and cor theory. Int. J. Contemp. Hosp. Manag. 2019, 31, 3742-3760. [CrossRef]

45. Ajzen, I. The theory of planned behavior, organizational behavior and human decision processes. J. Leis. Res. 1991, 50, $176-211$.

46. Bergel, M.; Brock, C. Visitors' loyalty and price perceptions: The role of customer engagement. Serv. Ind. J. 2019, 39, 575-589. [CrossRef]

47. Kim, J.; Lee, K.H. Influence of integration on interactivity in social media luxury brand communities. J. Bus. Res. 2017, 99, 422-429. [CrossRef]

48. Bergel, M.; Frank, P.; Brock, C. The role of customer engagement facets on the formation of attitude, loyalty and price perception. J. Serv. Mark. 2019, 33, 890-903. [CrossRef]

49. Derbaix, C.; Vanhamme, J. Inducing word-of-mouth by eliciting surprise-A pilot investigation. J. Econ. Psychol. 2003, 24, 99-116. [CrossRef]

50. Esmaeilpour, M.; Hoseini, S.Y.; Jafarpour, Y. An empirical analysis of the adoption barriers of e-commerce in small and medium sized enterprises (SMEs) with implementation of technology acceptance model. J. Internet Bank. Commer. 2016, 21, $28-57$.

51. Wu, C.; Chen, I.T. The essence of consumption attitude in high involvement purchase process. J. Int. Mark. Mark. Res. 2010, 35, 23-37.

52. Kim, J.; Ahn, K.; Chung, N. Examining the factors affecting perceived enjoyment and usage intention of ubiquitous tour information services: A service quality perspective. Asia Pac. J. Tour. Res. 2013, 18, 1-20. [CrossRef]

53. Holbrook, C.M.B. The chain of effects from brand trust and brand affect to brand performance: The role of brand loyalty. J. Mark. 2001, 65, 81-93.

54. Conner, M.; Armitage, C.J. Extending the theory of planned behavior: A review and avenues for further research. J. Appl. Soc. Psychol. 2010, 28, 1429-1464. [CrossRef] 
55. Cialdini, R.B.; Trost, M.R. Social influence: Social norms, conformity and compliance. In The handbook of Social Psychology; Gilbert, D.T., Fiske, S.T., Lindzey, G., Eds.; McGraw-Hill: New York, NY, USA, 1998; pp. 151-192.

56. Hung, S.Y.; Ku, C.Y.; Chang, C.M. Critical factors of wap services adoption: An empirical study. Electron. Commer. Res. Appl. 2004, 2, 42-60. [CrossRef]

57. Kleijnen, M.; Wetzels, M.; De Ruyter, K. Consumer acceptance of wireless finance. J. Financ. Serv. Mark. 2004, 8, 206-217. [CrossRef]

58. Tedeschi, J.T. Impression Management Theory and Social Psychological Research; Academic Press: New York, NY, USA, 2013.

59. Sawang, S.; Yuan, S.; Salim, S.A. It's not only what I think but what they think! The moderating effect of social norms. Comput. Educ. 2014, 76, 182-189. [CrossRef]

60. Gómez-Galán, J.; Vergara, D.; Ordóñez-Olmedo, E.; Veytia-Bucheli, M.G. Time of use and patterns of Internet consumption in university students: A comparative study between Spanish-speaking countries. Sustainability 2020, 12, 5087. [CrossRef]

61. Bagozzi, R.P.; Wong, N.; Abe, S.; Bergami, M. Cultural and situational contingencies and the theory of reasoned action: Application to fast food restaurant consumption. J. Consum. Psychol. 2000, 9, 97-106. [CrossRef]

62. Smith, J.R.; Louis, W.R. Do as we say and as we do: The interplay of descriptive and injunctive group norms in the attitudebehaviour relationship. Br. J. Soc. Psychol. 2011, 47, 647-666. [CrossRef]

63. Gillenson, M.L.; Sherrell, D.L. Enticing online consumers: An extended technology acceptance perspective. Inf. Manag. 2002, 39, 705-719.

64. Lu, J.; Yu, C.S.; Yao, J.E. Personal innovativeness, social influences and adoption of wireless internet services via mobile technology. J. Strateg. Inf. Syst. 2007, 14, 245-268. [CrossRef]

65. Cyr, D.; Hassanein, K.; Head, M.; Ivanov, A. The role of social presence in establishing loyalty in e-service environments. Interact. Comput. 2007, 19, 43-56. [CrossRef]

66. Cyr, D.; Head, M.; Ivanov, A. Design aesthetics leading to m-loyalty in mobile commerce. Inf. Manag. 2006, 43, 950-963. [CrossRef]

67. Seoyoung, K.; Sunny, H.; Hyeyoung, M.; Bee-Lia, C.; Heesup, H. Experience, brand prestige, perceived value (functional, hedonic, social, and financial), and loyalty among grocerant customers. Int. J. Hosp. Manag. 2018, 77, 169-177.

68. Anil, G.; Nikita, D. Tourist adoption of mapping apps: A UTAUT2 perspective of smart travellers. Tour. Hosp. Manag. 2017, 23, $145-161$.

69. Lee, S.; Kim, D.Y. The effect of hedonic and utilitarian values on satisfaction and loyalty of Airbnb users. Int. J. Contemp. Hosp. Manag. 2018, 30, 1332-1351. [CrossRef]

70. Ye, S.-T.; Zheng, J.; Zhang, J.; Ye, S.; Song, J.-W.; Bo, W.G. The operation of Hangzhou smart tourism project. Destech Trans. Econ. Bus. Manag. 2019, 30, 1332-1351. [CrossRef]

71. Huang, Y.; Poderi, G.; Šćepanović, S.; Hasselqvist, H.; Warnier, M.; Brazier, F. Embedding internet-of-things in large-scale socio-technical systems: A community-oriented design in future smart grids. In The Internet of Things for Smart Urban Ecosystems. Internet of Things (Technology, Communications and Computing); Cicirelli, F., Guerrieri, A., Mastroianni, C., Spezzano, G., Vinci, A., Eds.; Springer: Cham, Switzerland, 2019; pp. 125-150.

72. Lin, Y. E-urbanism: E-commerce, migration, and the transformation of Taobao villages in urban China. Cities 2019, 91, 202-212. [CrossRef]

73. Hair, J.F.; Ringle, C.M.; Sarstedt, M. Pls-sem: Indeed a silver bullet. J. Mark. Theory Pract. 2011, 19, 139-152. [CrossRef]

74. Hair, J.F.; Black, W.C.; Babin, B.J.; Anderson, R.E. Multivariate data analysis. Pearson Schweiz. Ag. 2013, 3, $128-134$.

75. Hair, J.F.; Sarstedt, M.; Pieper, T.M.; Ringle, C.M. The use of partial least squares structural equation modeling in strategic management research: A review of past practices and recommendations for future applications. Long Range Plan. 2012, 45, 320-340. [CrossRef]

76. Supanti, D.; Butcher, K. Is corporate social responsibility (CSR) participation the pathway to foster meaningful work and helping behavior for millennials? Int. J. Hosp. Manag. 2019, 77, 8-18. [CrossRef]

77. Ketchen, D.J. A primer on partial least squares structural equation modeling. Long Range Plan. 2013, 46, 184-185. [CrossRef]

78. Burke, J.C.; Mackenzie, S.B.; Podsakoff, P.M. A critical review of construct indicators and measurement model misspecification in marketing and consumer research. J. Consum. Res. 2003, 30, 199-218.

79. Sarstedt, M.; Schwaiger, M.; Taylor, C.R. Multigroup analysis in partial least squares (PLS) path modeling: Alternative methods and empirical results. Soc. Sci. Electron. Publ. 2011, 22, 195-218.

80. Henseler, J.; Ringle, C.M.; Sarstedt, M. Testing measurement invariance of composites using partial least squares. Soc. Sci. Electron. Publ. 2015, 49, 41-46. [CrossRef]

81. Cohen, J. Statistical power analysis for the behavioral sciences. Comput. Environ. Urban Syst. 1990, $14,71$.

82. Faul, F.; Erdfelder, E.; Buchner, A.; Lang, A.G. Statistical power analyses using G*Power 3.1: Tests for correlation and regression analyses. Behav. Res. Methods 2009, 41, 1149-1160. [CrossRef]

83. Yin, P.; Cai, A.-Y.; Yin, J. The research on Chinese family travelling decision-making and marketing suggestions for tourism destinations. In Proceedings of the 2009 IEEE/INFORMS International Conference on Service Operations, Logistics and Informatics, Chicago, IL, USA, 22-24 July 2009; IEEE: New York, NY, USA, 2009; pp. 524-527.

84. Christine Roy, M.; Dewit, O.; Aubert, B.A. The impact of interface usability on trust in web retailers. Internet Res. 2001, 11, 388-398. [CrossRef] 
85. Chen, K.C.; Gursoy, D.; Lau, K.L. Longitudinal impacts of a recurring sport event on local residents with different level of event involvement. Tour. Manag. Perspect. 2018, 28, 228-238. [CrossRef]

86. Bergkvist, L.I.; Rossiter, J.R. The Predictive Validity of Multiple-Item versus Single-Item Measures of the Same Constructs; American Marketing Association: New York, NY, USA, 2007.

87. Šegota, T.; Mihalič, T.; Kuščer, K. The impact of residents' informedness and involvement on their perceptions of tourism impacts: The case of Bled. J. Destin. Mark. Manag. 2017, 6, 196-206. [CrossRef]

88. Huang, L.; Chang, M. Why do travel agencies choose to undergo IPOS in Taiwan? Tour. Econ. 2017, 24, 79-91. [CrossRef]

89. Dyer, P.; Gursoy, D.; Sharma, B.; Carter, J. Structural modeling of resident perceptions of tourism and associated development on the sunshine coast, Australia. Tour. Manag. 2007, 28, 409-422. [CrossRef]

90. Shaykh-Baygloo, R. A multifaceted study of place attachment and its influences on civic involvement and place loyalty in Baharestan new town, Iran. Cities 2020, 96, 102473. [CrossRef]

91. Sinclair-Maragh, G. Demographic analysis of residents' support for tourism development in Jamaica. J. Destin. Mark. Manag. 2017, 6, 5-12. [CrossRef]

92. Hsu, L.C.; Wang, K.Y.; Chih, W.H.; Lin, W.C. Modeling revenge and avoidance in the mobile service industry: Moderation role of technology anxiety. Serv. Ind. J. 2019. [CrossRef]

93. Chen, C.F.; Chou, S.H. Antecedents and consequences of perceived coolness for generation y in the context of creative tourism: A case study of the Pier 2 Art center in Taiwan. Tour. Manag. 2018, 72, 121-129. [CrossRef]

94. Gursoy, D.; Ouyang, Z.; Nunkoo, R.; Wei, W. Residents' impact perceptions of and attitudes towards tourism development: A meta-analysis. J. Hosp. Mark. Manag. 2019, 28, 306-333. [CrossRef]

95. Su, L.; Swanson, S.R.; Chen, X. Reputation, subjective well-being, and environmental responsibility: The role of satisfaction and identification. J. Sustain. Tour. 2018, 26, 1-18. [CrossRef]

96. Bakhsh, J.; Potwarka, L.R.; Nunkoo, R.; Sunnassee, V. Residents' support for the Olympic games: Single host-city versus multiple host-city bid arrangements. J. Hosp. Mark. Manag. 2017, 27, 544-560. [CrossRef]

97. Zheng, Z.; Yaoqi, Z.; Yali, W. Residents' support intentions and behaviors regarding urban trees programs: A structural equation modeling-multi group analysis. Sustainability 2018, 10, 377.

98. Lehto, X.Y.; O'Leary, J.T.; Morrison, A.M. The effect of prior experience on vacation behavior. Ann. Tour. Res. 2004, 31, 801-818. [CrossRef]

99. Kline, R. Principles and Practice of Structural Equation Modeling; The Guilford Press: New York, NY, USA, 2005.

100. Yoo, B.; Donthu, N. Developing and validating a multidimensional consumer-based brand equity scale. J. Bus. Res. 2001, 52, 1-14. [CrossRef]

101. Worthington, R.L.; Whittaker, T.A. Scale development research: A content analysis and recommendations for best practices. Couns. Psychol. 2006, 34, 806-838. [CrossRef]

102. Yong, A.G.; Pearce, S. A beginner's guide to factor analysis: Focusing on exploratory factor analysis. Tutor. Quant. Methods Psychol. 2013, 9, 79-94. [CrossRef]

103. Gao, F.; Zhang, Y. Analysis of WeChat on iPhone. In 2nd International Symposium on Computer, Communication, Control and Automation; Atlantis Press: Amsterdam, The Netherlands, 2013; pp. 278-281.

104. Khechine, H.; Raymond, B.; Augier, M. The adoption of a social learning system: Intrinsic value in the UTAUT model. Br. J. Educ. Technol. 2020, 51, 2306-2325. [CrossRef]

105. He, K.; Zhang, J.; Zeng, Y. Households' willingness to pay for energy utilization of crop straw in rural China based on an improved UTAUT model. Energy Policy 2020, 140, 111373. [CrossRef]

106. Hair, J.F.; Hult, G.T.M.; Ringle, C.M.; Sarstedt, M. A Primer on Partial Least Squares Structural Equation Modeling (PLS-SEM); Sage publications: London, UK, 2016.

107. Hair Jr, J.F.; Sarstedt, M.; Hopkins, L.; Kuppelwieser, V.G. Partial least squares structural equation modeling (PLS-SEM): An emerging tool in business research. Eur. Bus. Rev. 2014, 26, 106-121. [CrossRef]

108. Chin, W.W.; Dibbern, J. A permutation based procedure for multi-group PLS analysis: Results of tests of differences on simulated data and a cross of information system services between Germany and the USA. In Modelización con Estructuras de Covarianzas en Ciencias Sociales: Temas Esenciales, Avanzados y Aportaciones Especiales; Netbiblo-Springer: London, UK, 2009 ; pp. 501-517.

109. Bagozzi, R.P. Evaluating structural equation models with unobservable variables and measurement error: A comment. J. Mark. Res. 1981, 18, 375-381. [CrossRef]

110. Chin, W.W. The partial least squares approach to structural equation modeling. Mod. Methods Bus. Res. 1998, 295, 295-336.

111. Henseler, J.R.; Ringle, C.M.; Sarstedt, M. A new criterion for assessing discriminant validity in variance-based structural equation modeling. J. Acad. Mark. Sci. 2015, 43, 115-135. [CrossRef]

112. Henseler, J.; Hubona, G.; Ray, P.A. Using pls path modeling in new technology research: Updated guidelines. Ind. Manag. Data Syst. 2016, 116, 2-20. [CrossRef]

113. Esposito Vinzi, V.; Chin, W.W.; Henseler, J.; Wang, H. Handbook of Partial Least Squares: Concepts, Methods and Applications; Springer: Heidelberg, Germany, 2010.

114. Diamantopoulos, A.; Siguaw, J.A. Formative versus reflective indicators in organizational measure development: A comparison and empirical illustration. Br. J. Manag. 2006, 17, 263-282. [CrossRef] 
115. Petter, S.; Straub, D.W.; Rai, A. Specifying formative constructs in information systems research. Mis Q. 2007, 31, 623-656. [CrossRef]

116. Sarstedt, M.; Ringle, C.M.; Henseler, J.; Hair, J.F. On the emancipation of PLS-SEM: A commentary on Rigdon. Long Range Plan. 2012, 47, 154-160. [CrossRef]

117. Rasoolimanesh, S.M.; Jaafar, M. Sustainable tourism development and residents' perceptions in world heritage site destinations. Asia Pac. J. Tour. Res. 2017, 22, 34-48. [CrossRef]

118. Shmueli, G.; Ray, S.; Estrada, J.M.V.; Chatla, S.B. The elephant in the room: Predictive performance of PLS models. J. Bus. Res. 2016, 69, 4552-4564. [CrossRef]

119. Evermann, J.; Tate, M. Assessing the predictive performance of structural equation model estimators. J. Bus. Res. 2016, 69, 4565-4582. [CrossRef]

120. Stone, M.P. Cross-validatory choice and assessment of statistical predictions. J. R. Stat. Soc. Ser. B (Methodol.) 1974, 36, 111-133. [CrossRef]

121. Geisser, S. The predictive sample reuse method with applications. J. Am. Stat. Assoc. 1975, 70, 320-328. [CrossRef]

122. Henseler, J.; Ringle, C.M.; Sinkovics, R.R. The use of partial least squares path modeling in international marketing. In New Challenges to International Marketing (Advances in International Marketing, Vol. 20); Sinkovics, R.R., Ghauri, P.N., Eds.; Emerald Group Publishing Limited: Bingley, UK, 2009; pp. 277-319.

123. Schlaegel, C.; Sarstedt, M. Assessing the measurement invariance of the four-dimensional cultural intelligence scale across countries: A composite model approach. Eur. Manag. J. 2016, 34, 633-649. [CrossRef]

124. Wetzels, M.; Odekerken-Schroeder, G.; Oppen, C.V. Using PLS path modeling for assessing hierarchical construct models: Guidelines and empirical illustration. Mis Q. 2009, 33, 177-195. [CrossRef]

125. Chin, W. How to write up and report PLS analyses. In Handbook of Partial Least Squares; Springer: Berlin/Heidelberg, Germany, 2010; pp. 655-690.

126. Dijkstra, T.K.; Henseler, J.R. Linear indices in nonlinear structural equation models: Best fitting proper indices and other composites. Qual. Quant. 2011, 45, 1505-1518. [CrossRef] 